\title{
Geoecology and Historical Heritage in the Ice-Free Area of Elephant Point (Antarctica). Proposal for Future Environmental Protection
}

\author{
Marc Oliva $^{1}$ • Jesús Ruiz-Fernández ${ }^{2}$ • Andrés Zarankin ${ }^{3}$ • Angélica Casanova-Katny ${ }^{4}$. \\ Jordi Nofre ${ }^{5}$
}

Received: 28 May 2015 / Accepted: 29 March 2016/Published online: 8 April 2016

(C) The European Association for Conservation of the Geological Heritage 2016

\begin{abstract}
The Antarctic Treaty provides the general environmental policies for all areas south of parallel $60^{\circ} \mathrm{S}$. In addition, some enclaves have a higher degree of environmental protection regulated by three categories: Antarctic Specially Protected Areas (ASPA), Antarctic Specially Managed Areas and Historic Sites or Monuments. Most of the protected areas in Antarctica have been designated based on the national geopolitical strategies, giving special attention to those areas where access and logistics are easier. This paper focuses on Elephant Point (Livingston, South Shetland Islands), an icefree area of $1.16 \mathrm{~km} 2$ where activities are only regulated by the Antarctic Treaty System and no further environmental protection exists. By using a geoecological approach based on the geomorphology together with the distribution of the fauna and flora existing in the area, we have distinguished six geoecological environments in Elephant Point: Rotch glacier, proglacial environment, moraine system, bedrock
\end{abstract}

Marc Oliva

oliva_marc@yahoo.com

1 Centre for Geographical Studies - Institute of Geography and Spatial Planning, University of Lisbon, Alameda da Universidade, 1600-214 Lisbon, Portugal

2 Department of Geography, University of Oviedo, Teniente Alfonso Martínez s/n, 33011 Oviedo, Spain

3 Department of Antrhopology and Archaeology, Universidade Federal de Minas Gerais, Av. Antonio Carlos, 6.627 - Campus Pampulha, 31., 270-901 Belo Horizonte, Brasil

4 Program in Environmental Studies (NEA), Catholic University of Temuco, Temuco, Chile

5 Interdisciplinary Center of Social Sciences, New University of Lisbon, Avenida de Berna 26-C, R+D Building, Room 3.14, 1069-061 Lisbon, Portugal plateaus, marine terraces and present-day beach. The distribution of fauna and flora is highly conditioned by the age of deglaciation as well as by the glacial, paraglacial and periglacial geomorphological landforms and processes. Besides this, five well preserved archaeological sites have been found in Elephant Point. These sites were used for sealers and whalers who sailed across the Maritime Antarctic during the eighteenth and nineteenth centuries. The rich biodiversity together with the high geomorphological and historical significance of this peninsula within the Maritime Antarctic constitutes the scientific basis to propose Elephant Point to be designated an ASPA in order to preserve the unique scientific heritage existing in this small peninsula.

Keywords Antarctica · Elephant Point · Geoecology · Archaeology $\cdot$ Antarctic Treaty System

\section{Introduction}

Antarctica is the landmass on Earth with the largest coverage of environmental protection at a continental scale derived from the Antarctic Treaty System. This treaty was signed in 1959 and implementation began in 1961; it details the activities that can be executed in this continent, mainly focused around research and the preservation of peace. Apart from the protection provided by this treaty to the lands and seas located at latitudes south of $60^{\circ} \mathrm{S}$ parallel, certain enclaves have special protection under the designation of the three categories defined by the Secretariat of the Antarctic Treaty:

i. Antarctic Specially Protected Areas (ASPA) for outstanding environments in terms of environmental, scientific, historical, aesthetic or wilderness values. There are a total 
of 75 such areas including surfaces ranging from 0.03 to $915.9 \mathrm{~km}^{2}$.

ii. Antarctic Specially Managed Areas (ASMA) for seven areas to assist in present and future research activities, improve international co-operation and avoid possible conflicts or minimise environmental impacts. The ASMA areas include larger surface areas than the ASPAs, of between 158.6 and $26,286 \mathrm{~km}^{2}$.

iii. Historic Sites or Monuments (HSM). A total of 90 sites valuable for their historical significance have been designated to date.

The protection of the present-day ASPAs began to be implemented during the late 1960s with the purpose of preserving the high scientific value of some environments. Most ASPAs are located in the scarce $0.4 \%$ ice-free surface in Antarctica, with a couple of them corresponding to offshore marine environments. The access to these specially protected areas as well as the activities that can be conducted there are defined by the management plans regulating them.

The ecology and landscape of the ASPAs have been historically the key values for their designation (Hughes and Convey 2010). However, these management plan regulations have focused on the single description of the scientific values (fauna, flora, geology) without including their interactions from an integrated and dynamic approach. These studies analysing the biotic and abiotic elements that characterise the environmental dynamics can be examined using a geoecological approach (Troll 1968, 1972) which has been little addressed until now in the context of polar regions (e.g. Troll 1973; Ives and Barry 1974; Mora et al. 2015).

Environmental protection in Antarctica has received renewed attention over the last few years due to the increase in the number and typology of scientific activities carried out in some areas as well as the increasing tourism pressure in certain sites of the Maritime Antarctic (Enzenbacher 2007; Convey et al. 2012; Hughes et al. 2013; Verbitsky 2013). Furthermore, protection has been claimed not to be fully representative of covering the several distinct bioregions in Antarctica (Terauds et al. 2012). Recently, some studies have also evaluated from a scientific perspective the research interests and the implementation of the environmental management in some ASPAs several decades after their designation (Benayas et al. 2013). Most of the areas in Maritime Antarctica under environmental protection as ASPAs are located in sites where logistic support is facilitated by the presence of bases and shelters. Thus, in the majority of the cases, the ASPA designation was handled by the national Antarctic programmes operating such infrastructures and spaces. In this context, a gap is detected in the protection of certain enclaves that - despite their remarkable geoecological heritage - are not located within the traditional scientific interests, or constrained by geopolitical strategies, or in areas where access and logistics are more difficult.

In the case of the western end of Livingston Island, namely in Byers Peninsula, Britain and Chile proposed to protect it in 1966, paving the way for the present-day legislation set by ASPA 126. This area of approximately $60 \mathrm{~km}^{2}$ is the largest glacier-free area of the South Shetland Islands (SSI). It was designated ASPA because it houses the largest biodiversity of the Maritime Antarctic (Toro et al. 2007; Quesada et al. 2013). However, there are a set of small ice-free peninsulas around Byers that concentrate a wide variety of fauna, flora and geomorphological landforms and processes that are not subject to any kind of protection.

This is the case for the peninsula of Elephant Point, a small deglaciated environment located only $3 \mathrm{~km}$ east of Byers, which does not have any environmental protection despite its exceptional geomorphological, biological and landscape heritage. The aim of this paper is to examine the geoecological values of this enclave in order to discuss, from a scientific and not geopolitical point of view, the possibility of endowing this space with the designation of an environmental framework in the context of the environmentally protected areas in Antarctica.

\section{Study Area}

The SSI is an archipelago aligned longitudinally SW-NE along $300 \mathrm{~km}$ in the north-west façade of the Antarctic Peninsula. This archipelago consists of 10 islands, of which King George $\left(1250 \mathrm{~km}^{2}\right)$ and Livingston $\left(818 \mathrm{~km}^{2}\right)$ islands are the largest.

Climate regime in this archipelago is characterised by mean annual air temperatures of -1 to $-2{ }^{\circ} \mathrm{C}$ at sea level, with annual precipitations of 500-800 mm (Bañón et al. 2013). These conditions explain why these islands are extensively glaciated, with a glacierised surface ranging from $57 \%$ in the case of the volcanic Deception Island (López-Martínez and Serrano 2002) to $100 \%$ in Snow Island. The ice cover in Livingston extends over $84 \%$ of the island (Osmanoglu et al. 2014), and Byers Peninsula constitutes the largest part of the remaining $16 \%$ deglaciated surface. In turn, in the margins of this island, there are several small ice-free peninsulas with a surface of ca. $1-1.5 \mathrm{~km}^{2}$, such as Elephant Point. The gradual shrinkage of the glacier Rotch dome during the Holocene in response to the prevailing climate conditions has conditioned the appearance of these ice-free environments (Oliva et al. 2014).

The lithology of the exposed bedrock in the deglaciated environments of the archipelago is mostly volcanic, with an abundance of strongly weathered basaltic material due to physical weathering processes. Periglacial processes are widespread in glacier-free areas, with sporadic or discontinuous permafrost below $25-30 \mathrm{~m}$ turning to continuous above this 
level (Serrano et al. 2008; Vieira et al. 2010). The vegetation is very scarce, mainly composed of communities of mosses and lichens, with presence of the only two native vascular plants in Antarctica: Deschampsia antarctica and Colobanthus quitensis (Vera 2011). In the coastal environments of the SSI, the rich and abundant wildlife is widespread.

Elephant Point is an ice-free peninsula of $1.16 \mathrm{~km}^{2}$ in the SW of Livingston Island (Fig. 1). It is limited by the Rotch dome glacier in the north and the sea encircling the rest of its margins. Elevations only exceed $50 \mathrm{~m}$ in the internal ridge of the frontal moraine. Nowadays, there is no seasonal or permanent human presence in this peninsula, which has minimised human impact at this location. However, five sites of archaeological interest have been identified in Elephant Point that are probably related to the first sealers and whalers who sailed across the SSI during the eighteenth and nineteenth centuries (Zarankin and Senatore 2005, 2007). These archaeological sites are examined in this paper.

\section{Materials and Methods}

Fieldwork was carried out in late January and early February 2014. A detailed geoecological mapping was conducted in Elephant Point when the snow cover had melted, including the distribution of the main geomorphological landforms as well as the spatial distribution of the fauna and flora existing in the peninsula.

The percentage of deglaciated surface in Elephant Point between 1956 and 2010 was calculated based on the comparison between the aerial image from 1956 (US Geological Survey, 17 December 1956) and the snow-free satellite image of Google Earth from 2010.

Fig. 1 Location of Elephant Point peninsula
A first archaeological survey was conducted in February 2013, which allowed identification of most of the sites examined in February 2014. Sites EP-2 and EP-X1 were selected for a detailed archaeological investigation. An important collection of artefacts was recovered from them, even if they were not completely excavated (75\% in site EP-2 and $60 \%$ in EP-X1), since part of the sites must be left for possible future archaeological studies in the area. The other sites in Elephant Point were accurately described, photographed and recorded, and the information included in a database of the SSI archaeological record.

\section{Geoecological Environments in Elephant Point}

Geomorphological units were used as the basis for mapping the distribution of the different geoecological environments in Elephant Point. Six different areas were identified (Table 1 and Fig. 2):

\section{Rotch Glacier}

The dome shows vertical fronts falling to the sea (glacier calving) and gentle slopes in the central area. The ice thickness increases gradually towards the north, reaching a maximum accumulation of ice of ca. $150 \mathrm{~m}$ at the highest point of the dome (Macheret et al. 2009). The biological activity is very poor on the surface of the glacier, only restricted to its margins along the coast, where the presence of individual specimens of southern giant petrels (Macronectes giganteus), chinstrap penguins (Pygoscelis antarctica) and Weddell seals (Leptonychotes weddellii) was observed. Along the edges of the glacier near the coast, red spots related to the presence of

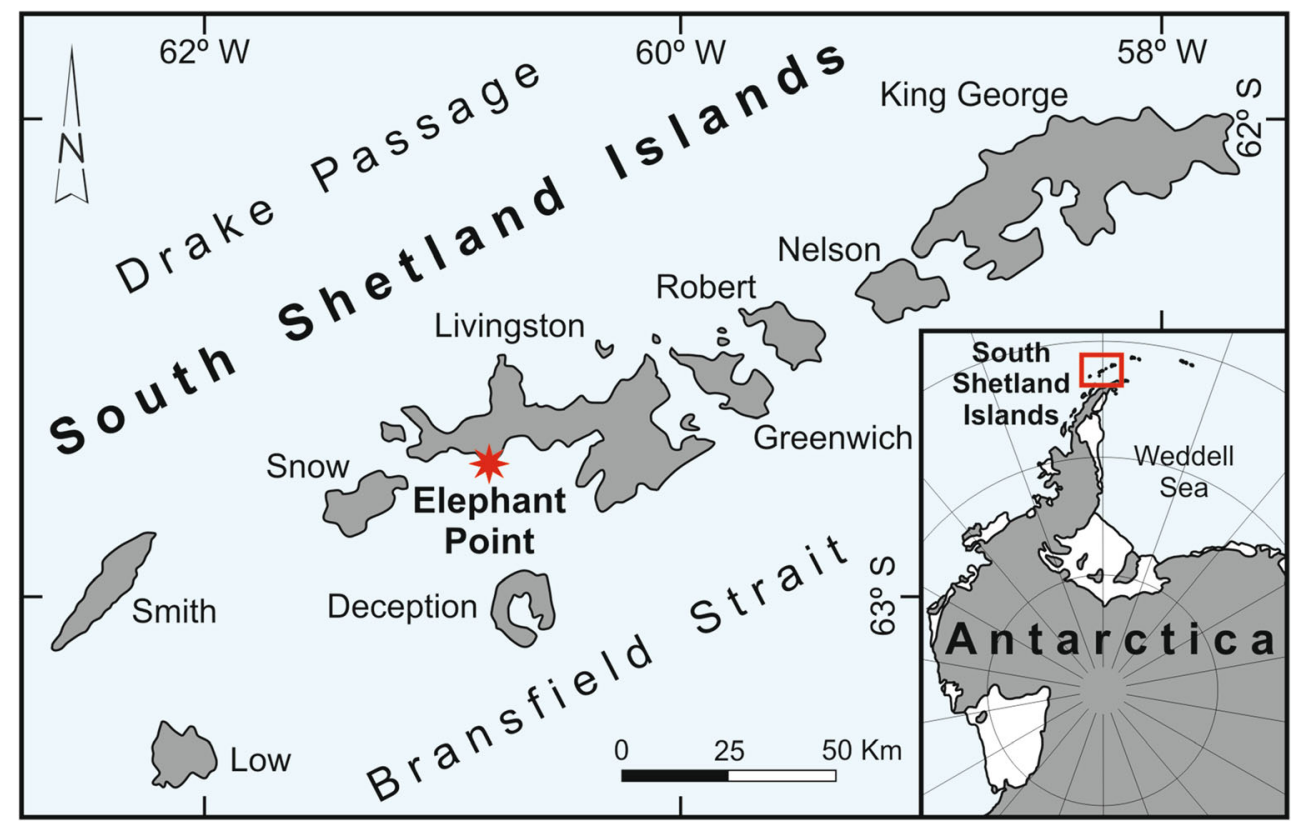


Table 1 Geomorphological landforms, fauna and flora in each of the six geoecological environments identified in Elephant Point

\begin{tabular}{|c|c|c|c|c|}
\hline Environments & $\begin{array}{l}\text { Surface }\left(\mathrm{km}^{2}\right) \\
(\% \text { of the total })\end{array}$ & Landforms & Fauna & Flora \\
\hline Rotch glacier & - & Dome, glacier calving & $\begin{array}{l}\text { Giant petrels, chinstrap } \\
\text { penguins, Weddell seals }\end{array}$ & Snow algae \\
\hline Proglacial environment & $0.06(5.2)$ & $\begin{array}{l}\text { Squeeze moraines, stone } \\
\text { sorted-circles, stone } \\
\text { stripes, alluvial fans, } \\
\text { kettle lakes }\end{array}$ & $\begin{array}{l}\text { Giant petrels, chinstrap } \\
\text { penguins, elephant seals, } \\
\text { Antarctic fur seals }\end{array}$ & $\begin{array}{l}\text { Mosses (e.g. Sanionia uncinata, } \\
\text { Warnstorfia spp.) }\end{array}$ \\
\hline Moraine system & $0.3(25.9)$ & $\begin{array}{l}\text { Polished blocks, pronival } \\
\text { ramparts, frost mounds, } \\
\text { sorted-circles, stone stripes, } \\
\text { solifluction landforms, } \\
\text { slumps, landslides, lakes, } \\
\text { lagoons }\end{array}$ & $\begin{array}{l}\text { Giant petrels, Antarctic terns, } \\
\text { skuas }\end{array}$ & $\begin{array}{l}\text { Vascular plants (Deschampsia } \\
\text { antarctica, Colobanthus quitensis), } \\
\text { lichens (Usnea antarctica, Usnea } \\
\text { aurantiaco-atra) }\end{array}$ \\
\hline Bedrock plateaus & $0.25(21.6)$ & $\begin{array}{l}\text { Polished surfaces, stone } \\
\text { sorted-circles, stone stripes, } \\
\text { earth hummocks, solifluction } \\
\text { landforms, talus cones, } \\
\text { rockfalls }\end{array}$ & $\begin{array}{l}\text { Gentoo penguins, giant petrels, } \\
\text { Antarctic terns, skuas }\end{array}$ & $\begin{array}{l}\text { Mosses (Andreae gainii, Sanionia sp., } \\
\text { Andreae depressinervis), lichens } \\
\text { (Usnea antarctica, Usnea } \\
\text { aurantiaco-atra, Umbilicaria } \\
\text { antarctica, Rhizocarpon } \\
\text { geographicum, Caloplaca regalis, } \\
\text { Xanthoria elegans, Haematomma } \\
\text { erythroma) and vascular plants } \\
\text { (Deschampsia antarctica, } \\
\text { Colobanthus quitensis) }\end{array}$ \\
\hline Marine terraces & $0.45(38.8)$ & $\begin{array}{l}\text { Marine terraces, tombolos, } \\
\text { lagoons, alluvial fans, } \\
\text { mudboils, penguin mounds, } \\
\text { Elephant seal scars }\end{array}$ & $\begin{array}{l}\text { Giant petrels, gentoo and } \\
\text { chinstrap penguins, } \\
\text { elephant seals, Antarctic } \\
\text { fur seals, Weddell seals, } \\
\text { giant petrels, skuas }\end{array}$ & $\begin{array}{l}\text { Vascular plants (Deschampsia } \\
\text { antarctica, Colobanthus quitensis), } \\
\text { mosses (Sanionia uncinata, } \\
\text { Warnstorfia spp., Polytrichastrum } \\
\text { alpinum, Andreaea gainii), lichens } \\
\text { (Usnea aurantiaco-atra, Usnea } \\
\text { antarctica, Umbilicaria antarctica, } \\
\text { Ochrolechia frigida, Rhizocarpon } \\
\text { geographicum, Haematomma } \\
\text { erythroma, Caloplaca regalis, } \\
\text { Xanthoria elegans), cyanobacteria } \\
\text { (Phormidium sp.) }\end{array}$ \\
\hline Present-day beach & $0.1(8.6)$ & Beach, tombolos, cliffs & $\begin{array}{l}\text { Giant petrels, gentoo and chinstrap } \\
\text { penguins, elephant seals, } \\
\text { Antarctic fur seals, Weddell } \\
\text { seals, leopard seals, giant } \\
\text { petrels, skuas, }\end{array}$ & Marine algae \\
\hline
\end{tabular}

snow algae communities (Chlamydomonas sp. and Chloromonas sp.) were identified on the snow surface (Remias et al. 2013).

\section{Proglacial Environment}

This recently deglaciated environment has remained ice-free during the last few decades. The comparison between the aerial picture of 1956 and the satellite image from 2010 shows evidence of the accelerated retreat of the glacier (Fig. 3). The new exposed surface accounts for $17.3 \%$ of the total current ice-free surface in this peninsula (Oliva and Ruiz-Fernández 2015). This area is constituted by two relatively flat surfaces in both margins of the peninsula with a central plateau where decimetric patterned ground features are present. This plateau acts as a watershed for the streams flowing seawards towards the eastern and western coasts where they have created alluvial fans. In the western fan, tens of kettle lakes are scattered (Fig. 2). In the proglacial environment, the biological activity is limited, with incipient mosses (e.g. Sanionia uncinata, Warnstorfia spp.), birdlife (giant petrels, chinstrap penguins) and presence of two colonies of elephant seals (Mirounga leonina) in the alluvial fans close to the coastline. Other pinnipeds such as Antarctic fur seals (Arctocephalus gazelle) were also observed in this space.

\section{Moraine System}

This constitutes the transition area between the glacier and the environment under marine influence. It is composed of a 


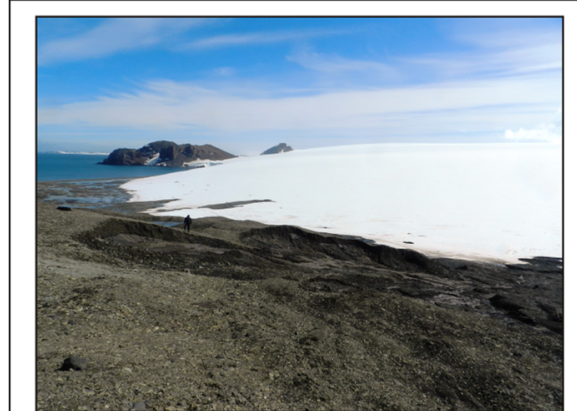

Glacier

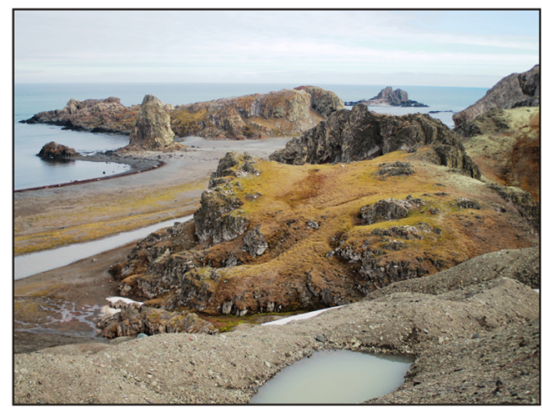

Bedrock plateaus

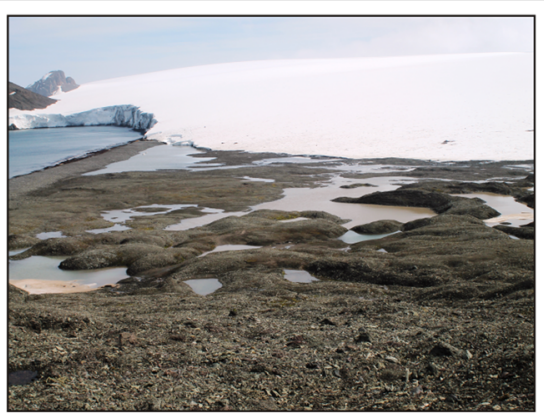

Proglacial environment

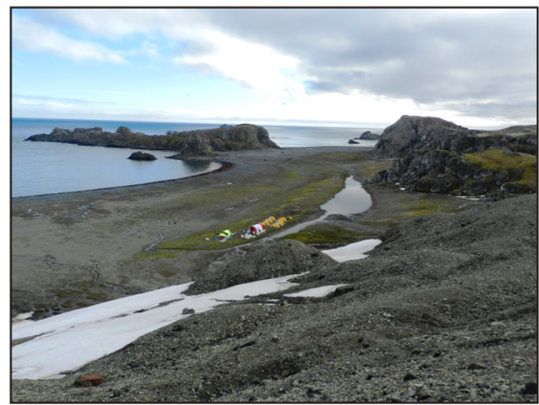

Marine terraces

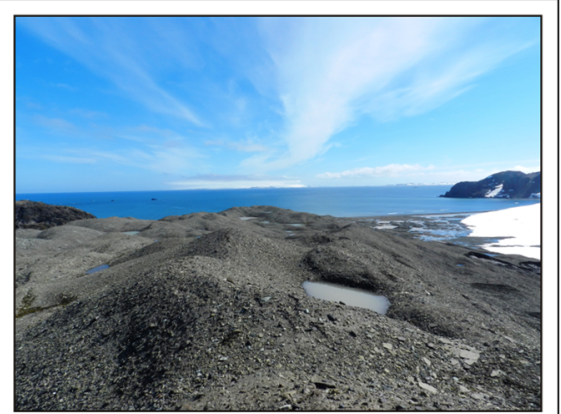

Moraine system

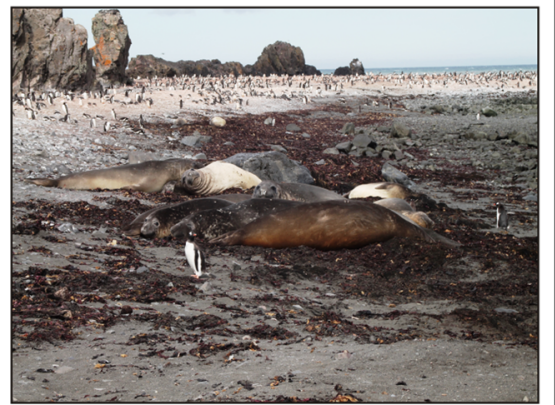

Present-day beach

Fig. 2 The different geoecological environments in Elephant Point

series of overlapping arches extending from the western to the eastern edges of the peninsula, of which the inner and outer ridges constitute the highest elevations of Elephant Point (55 and $45 \mathrm{~m}$, respectively). The inner slope of the moraine is affected by paraglacial dynamics, since the glacier occupied this area during the first half of the twentieth century and became ice-free only after 1956 . As a consequence, very active periglacial slope processes are reworking the unconsolidated sediments of the moraine through landslides, slumps and solifluction processes (Oliva and Ruiz-Fernández 2015), which impedes vegetation colonisation. The biological activity consists mainly of mosses in poorly drained and flooded areas distributed in the hummocky terrain between the two main moraine ridges which are undergoing permafrost degradation: isolated specimens of $D$. antarctica and $C$. quitensis, and incipient lichens (basically Usnea antarctica and Usnea aurantiaco-atra). The southern slope of the moraine is more stable, since paraglacial processes are no longer active here. However, nival processes have formed three active pronival ramparts at the foot of long-lying snow patches. The vegetation on the southern hillside is also very scarce and only represented by isolated lichens and mosses in the contact between the moraine and the uppermost marine terraces favoured by the accumulation of snow melting waters. Birdlife was occasionally observed in the moraine, mainly giant petrels, Antarctic terns (Sterna vittata) and skuas (Stercorarius antarcticus).

\section{Bedrock Plateaus}

The existence of polished surfaces and glacial striae in some of the plateaus outside from the moraine complex suggests that the Rotch dome overrode these areas several millennia ago, before the formation of the moraine system. These basalt rock surfaces located at a higher elevation than the Holocene marine terraces show thick and dense crustose and fruticose lichen formations ( $U$. antarctica, U. aurantiaco-atra, Umbilicaria antarctica, Rhizocarpon geographicum) and mosses such as Andreae gainii. Vascular plants (D. antarctica and $C$. quitensis) are distributed on flat surfaces. There are also large areas of patterned ground landforms (e.g. sorted stone circles, stone stripes) where fine-grained soils appear. Several colonies of giant petrels, Antarctic terns and skuas are distributed in the upper surfaces of the plateaus. In the southernmost bedrock plateau, there is a large colony of gentoo penguins (Pygoscelis papua). Next to these colonies, thick organic-rich ornithogenic soils are covered by moss carpets of Sanionia sp. and Andreae depressinervis, together with some crustose and ornithocoprophilus lichens on rock surfaces (Caloplaca regalis, Xanthoria elegans, Haematomma erythroma). Some solifluction lobes and earth hummocks have developed on these densely vegetated surfaces. The contact between the moraine and the marine terraces with these bedrock plateaus is steep, with vertical slopes favouring rockfalls and talus cones at their foot. In most cases, the abundance of lichens 


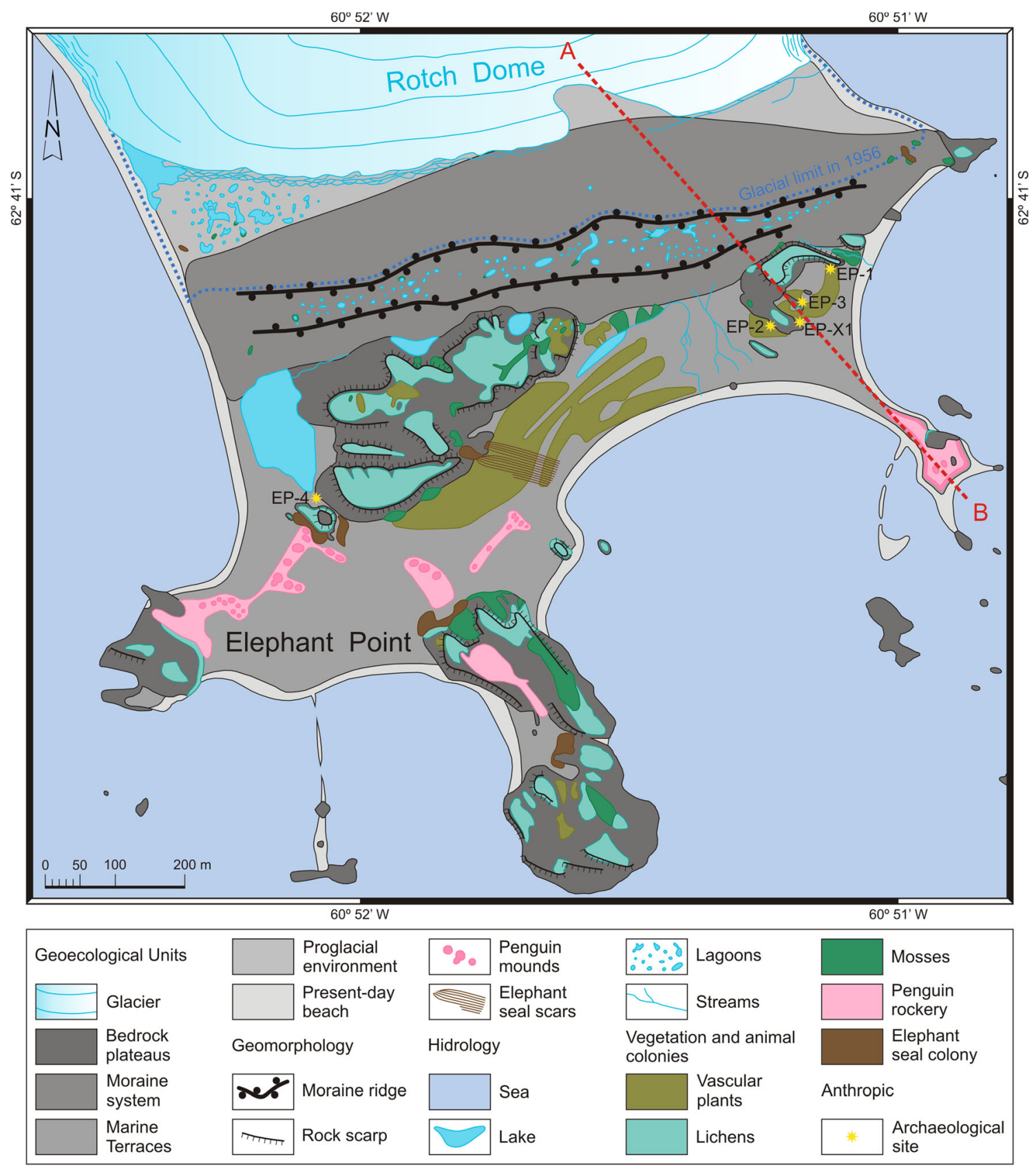

Fig. 3 The comparison between the aerial picture of 1956 and the satellite image from 2010

in the surface of the rocks forming the talus cones suggests the current stability of the rockfalls in these areas.

\section{Marine Terraces}

Five levels of marine terraces are distributed at elevations of 2 , $3,5,7$ and $10 \mathrm{~m}$. There are semi-permanent lagoons in the highest raised beaches with abundant mats of cyanobacteria (Phormidium sp.). In the area between the moraine and the marine terraces, several alluvial fans are distributed. On these landforms, there are mosses such as S. uncinata and
Warnstorfia spp. forming carpets on flooded areas. In the terraces, there are sites where cryoturbation is very active, forming mudboils, which impedes vegetation growth. However, vegetation cover is generally abundant on the flat surfaces of the marine terraces, with abundance of vascular plants (D. antarctica and C. quitensis), and mosses such as Polytrichastrum alpinum and lichens, especially on the small basalt outcrops standing out of the terraces. Fruticose lichens, such as $U$. aurantiaco-atra and $U$. antarctica, foliose such as $U$. antarctica and crustose such as Ochrolechia frigida and $R$. geographicum, are distributed on them as well as some 
mosses such as Andreaea gainii. In areas where bird colonies are present, there are crustose lichens (H. erythroma, C. regalis, $X$. elegans).

Wildlife is abundant in all terraces, with four colonies of gentoo penguins and five of elephant seals. The action of the elephant seals has a double effect: it creates scars on its way between the sea and the colonies existing in the highest terraces, but also contributes to fertilising the ground in these areas, generating thick organic-rich soils. Penguin rockeries are present in the lowest terraces $(2,3$ and $5 \mathrm{~m})$, and there are also remains of formerly active colonies in the terraces distributed at elevations of 5 and $7 \mathrm{~m}$. These guano deposits form mounds that can reach $5 \mathrm{~m}$ long and $1 \mathrm{~m}$ high. They have been used to infer the former distribution of the penguin population through the radiocarbon dating of these organic-rich deposits, suggesting significant changes in their distribution in the SSI through the Middle-Late Holocene (del Valle et al. 2002; Emslie 1995). The existence of elephant seal and penguin carrion lying on the marine terraces attracts abundant giant petrels and skuas in this area. In the penguin rockeries, birdlife is also very active, with giant petrels and skuas feeding on live and dead penguin chicks. Isolated chinstrap penguins, Weddell seals and Antarctic fur seals were observed in the lowest marine terraces near the sea.

\section{Present-Day Beach}

The present-day beach is largely affected by the tides that have a range of several metres in this portion of the Maritime
Antarctic (King and Padman 2005). The low tide exposes two tombolos in the central bay and another one in the westernmost bay. The intertidal zone is characterised by the absence of terrestrial vegetation, with abundant marine algae in some areas and intense use by wildlife, namely elephant seals, individual penguins and birds. Specimens of Weddell seals, Antarctic fur seals and leopard seals (Hydrurga leptonyx) were observed along the beach. In the cliffs and rocky beaches, birdlife is dominant, with presence of gentoo penguins, chinstrap penguins, giant petrels and Antarctic terns (Table 2).

\section{The First Settlers and the Historical Human Impact in Elephant Point}

Five human-built rock shelters were found distributed across the highest marine terraces in Elephant Point at the foot of the bedrock plateaus. These shelters show the same structure observed in the nearby Byers Peninsula: they were built in natural shelters, such as caves or open air rock formations, using those natural features as walls and piling up local stones to close them (Zarankin and Senatore 2005). Most of these shelters show well-preserved square, rectangular or semicircular structures with one or more entrances (Fig. 4). They have a surface between 15 and $20 \mathrm{~m}^{2}$. A wide range of whale vertebrae, ribs, and jaw pieces were spread across these sites.

After a preliminary archaeological reconnaissance, the sites EP-2 and EP-X1 were selected for detailed excavations for being the areas with higher archaeological potential. The
Table 2 Location and main characteristics of the archaeological sites found in Elephant Point

\begin{tabular}{|c|c|c|}
\hline Archaeological sites & Coordinates & Main characteristics \\
\hline Elephant Point 1 (EP-1) & $\begin{array}{l}62^{\circ} 41^{\prime} 27.3^{\prime \prime} \mathrm{S} \\
60^{\circ} 51^{\prime} 36.3^{\prime \prime} \mathrm{W}\end{array}$ & $\begin{array}{l}\text { Single small space next to a rock formation. } \\
\text { This site was not excavated. }\end{array}$ \\
\hline Elephant Point 2 (EP-2) & $\begin{array}{l}62^{\circ} 41^{\prime} 06.9^{\prime \prime} \mathrm{S} \\
60^{\circ} 51^{\prime} 13.8^{\prime \prime} \mathrm{W}\end{array}$ & $\begin{array}{l}\text { This site is encompasses a surface of } 15 \mathrm{~m}^{2} \\
\text { surrounded by rock walls. Several } \\
\text { whalebones were used as furniture and } \\
\text { also as part of the roof structure. It was the } \\
\text { living space for cooking and sleeping. } \\
\text { This site is interpreted to be the primary shelter } \\
\text { of the sealers. }\end{array}$ \\
\hline Elephant Point 3 (EP-3) & $\begin{array}{l}62^{\circ} 41^{\prime} 05.5^{\prime \prime} \mathrm{S} \\
60^{\circ} 51^{\prime} 10.8^{\prime \prime} \mathrm{W}\end{array}$ & $\begin{array}{l}\text { It consists of two small spaces built against a } \\
\text { rocky outcrop. } \\
\text { The walls are made of piled rocks, as in most } \\
\text { of the sealing sites in Livingston Island. This } \\
\text { site was not excavated. }\end{array}$ \\
\hline Elephant Point 4 (EP-4) & $\begin{array}{l}62^{\circ} 41^{\prime} 03.5^{\prime \prime} \mathrm{S} \\
60^{\circ} 51^{\prime} 10.8^{\prime \prime} \mathrm{W}\end{array}$ & $\begin{array}{l}\text { It is a small space made with rocks and } \\
\text { whalebones. The walls consist of stacked } \\
\text { rocks, although the state of conservation is } \\
\text { very poor. } \\
\text { This site was not excavated. }\end{array}$ \\
\hline Elephant Point X1 (EP-X1) & $\begin{array}{l}62^{\circ} 68^{\prime} 51.8^{\prime \prime} \mathrm{S} \\
60^{\circ} 85^{\prime} 34.0^{\prime \prime} \mathrm{W}\end{array}$ & $\begin{array}{l}\text { This site has a surface area of } 16 \mathrm{~m}^{2} \text {. It is } \\
\text { interpreted to be the working place used } \\
\text { by the same people who lived in EP- } 2 \text {. }\end{array}$ \\
\hline
\end{tabular}


Fig. 4 The five human-built rock shelters found distributed across the highest marine terraces in Elephant Point

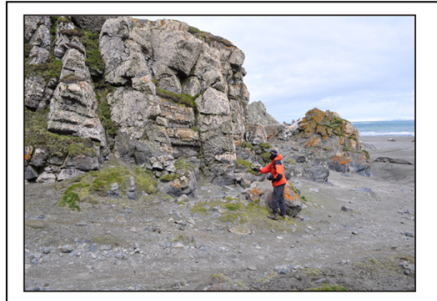

EP - 1

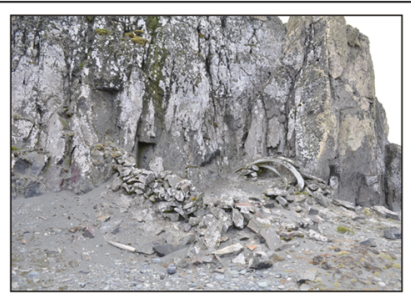

EP - 2

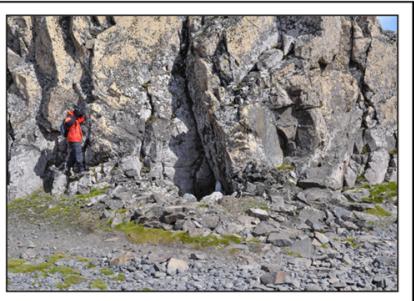

EP - 3
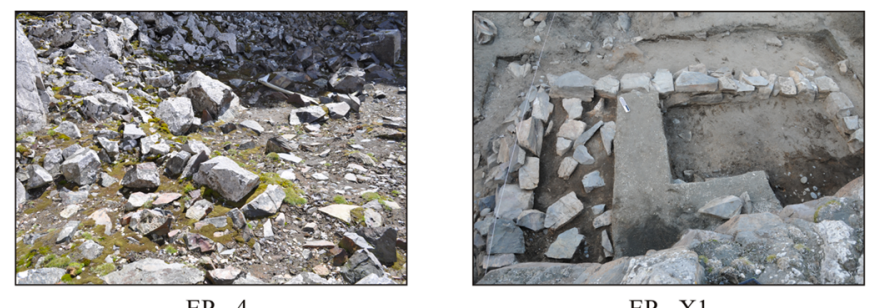

EP - X1

archaeological collection recovered from both sites consists basically of iron artefacts, bone fragments, textile articles and fragments of ceramic and wood.

\section{EP-2}

This extremely well-preserved site comprises a square surface of $15 \mathrm{~m}^{2}$ ( $5 \mathrm{~m}$ long, $3 \mathrm{~m}$ wide) under the shelter of a rocky outcrop at only $70 \mathrm{~m}$ from the sea and at ca. $600 \mathrm{~m}$ from the closest fresh water source. It is enclosed by walls ( $0.4 \mathrm{~m}$ thick) of piled rocks, one of which is virtually intact. Inside, interestingly, whale ribs lie in their original position acting as the rafters, together with the jaw of this large animal (Fig. 5).

\section{EP-X1}

This archaeological site is located in a corner of a rocky outcrop at a distance of only $50 \mathrm{~m}$ from the sea and at ca. $550 \mathrm{~m}$ from the fresh water. The site is enclosed by 0.8 -m-thick walls of stacked rocks forming a rectangular shape area of $16.8 \mathrm{~m}^{2}$ (6 m long, $2.8 \mathrm{~m}$ wide). It shows a continuous area, without space divisions, and a large stove area inside (Fig. 5). There is also another stove site outside of the opposite wall of the outcrop (Fig. 6).

\section{Discussion}

The geoecological and archaeological surveying carried out in Elephant Point has shown evidence of the high ecological values of the terrestrial ecosystem and the important historical significance of this ice-free area in the context of the Maritime Antarctic.

\section{The Geomorphological and Geoecological Heritage}

The ice-free area of Elephant Point constitutes essentially a maritime permafrost environment with a wide range of landforms and processes characteristic of the glacial and periglacial maritime polar regions. According to measurements of the frozen soil depth as well as visual observations in the field, permafrost is widespread nowadays in Elephant Point, even down to sea level (Oliva and Ruiz-Fernández 2015).
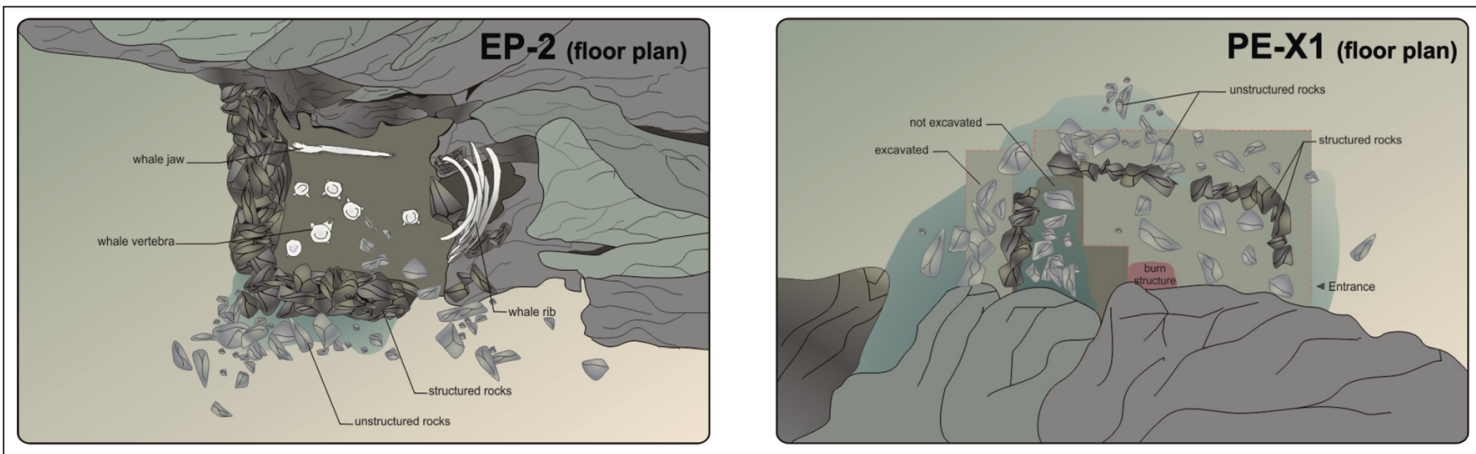

Fig. 5 The archaeological sites EP-2 and EPX1 


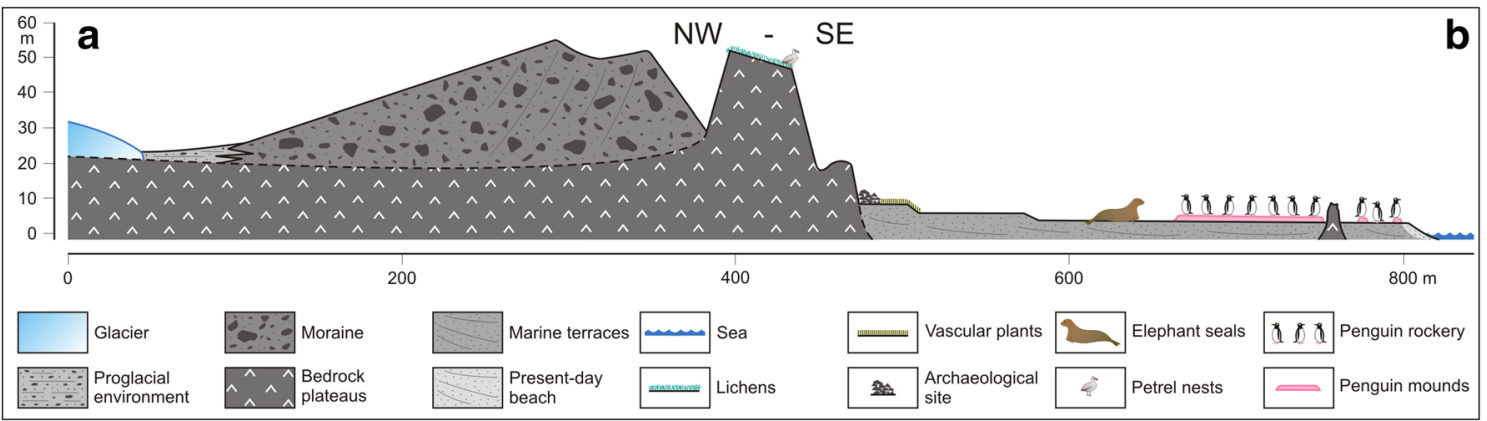

Fig. 6 The geomorphological and geoecological heritage of Elephant Point

All the ice-free geoecological environments identified in Elephant Point are a consequence of the retreat of Rotch glacier. The geoecological response to postglacial environmental change depends, therefore, on the time of exposure of the terrain to ice-free conditions, topography and climate variability. Based on geomorphological evidences and the comparison with the nearby ice-free area of Byers Peninsula, we assume that the retreat of the Rotch dome in Elephant Point is of Holocene age. This retreat was not linear over time, with some periods of glacier regrowth that generated the extensive moraine system composed of several arches. At the same time, the long-term glacier retreat was accompanied by a significant glacio-isostatic uplift (Fretwell et al. 2010; Watcham et al. 2011) that led to the formation of several levels of marine terraces. In the uppermost terraces, patterned ground and mudboils are present, which is indicative of the intensity of cryoturbation processes in the area over the last 500 years (Oliva and Ruiz-Fernández 2015). The glacier retreat has accelerated over the last decades in response to the recent warming detected in the Antarctic Peninsula region (Turner et al. 2005; Steig et al. 2009). As a result, $17.3 \%$ of the total land surface exposed today in Elephant Point appeared after 1956, which has intensified the geomorphic activity through a wide range of paraglacial processes in this area (Oliva and Ruiz-Fernández 2015). Also, thermokarst processes are also intense in the recently deglaciated areas of flat topography in the western fringe of Elephant Point (Oliva and Ruiz-Fernández 2015), as it has been also observed in other deglaciated environments across the SSI (López-Martínez et al. 2012).

The distribution of the flora in Elephant Point follows a geographical pattern directly linked to the age of deglaciation. Casanova-Katny and Cavieres (2012) also found a close relationship between the age of deglaciation and the distribution of certain species in different locations from the Antarctic Peninsula region. The colonisation of vegetation in the icefree areas in the Maritime Antarctic is still under debate, and some studies point to the small ice-free environments as key areas in their expansion (Torres-Mellado et al. 2011). Whilst the recently deglaciated geomorphological environments in Elephant Point show a very sparse vegetation cover with very few species, the oldest ice-free areas have a more abundant distribution of grasses, mosses and lichens with a higher degree of biodiversity. The distribution of some species such as $U$. aurantiaco-atra shows a close relationship with the presence of snow cover, as also observed in other ice-free maritime environments of the SSI (Vieira et al. 2014). By contrast, the distribution of fauna is clearly dependent on the distance with respect to the shoreline, especially in the case of the animals breeding directly from the sea (e.g. penguins, seals). It is also constrained by microclimatic conditions such as the exposure to prevailing winds, which determines the location of elephant seal colonies and the number of specimens in each of them. The birdlife shows a similar pattern, though birds generally prefer higher locations from which they observe their potential prey located across the marine terraces and the beach.

Apparently, the Rotch dome glacier in the area of Elephant Point has poor biological activity, although it should be taken into account that there is increasing evidence that polar glaciers have been shown to support a large number of microbial communities (Anesio et al. 2007; Anesio and Laybourn-Parry 2012; Mieczan et al. 2013). In the proglacial environment and moraine plateau, there are only a few lichens in stable rocks and mosses in flat areas surrounding lagoons. These waters come from the snow melting at the beginning of the melting season as well as the thawing of the active layer of the permafrost. There is a clear contrast between the inner and outer ridges of the moraine due to the different stages of paraglacial activity to which they are exposed (Oliva and Ruiz-Fernández 2015). The recently deglaciated slope is being affected by very intense geomorphic activity that promotes the mobilisation of sediments and impedes the growth of lichens and mosses.

The bedrock plateaus constitute one of the oldest geomorphological features in the peninsula. Their long-term exposure to ice-free conditions has resulted in the extensive coverage of thick lichen mats across the plateaus. They are also intensely used by bird colonies, which have generated thick ornithogenic soils. These soils have been 
observed widely across the SSI, both at the foot of active penguin and bird colonies and in formerly active ones (Michel et al. 2006, 2014).

The marine terraces are the environments showing the richest biodiversity in Elephant Point, both in terms of fauna and flora. These areas have been exposed as land surface since at least the last few centuries, to millennia in the case of the highest terraces (Oliva and Ruiz-Fernández 2015), which has resulted in an abundance and high degree of diversity of the communities of mosses, lichens and grasses. The flat surface of the terraces close to the shoreline also favours the intense use by seals, penguins and all kinds of birds. This geographical pattern is also observed in the nearby Byers Peninsula as well as in other ice-free sites in the SSI and Antarctic Peninsula regions (Torres-Mellado et al. 2011; Casanova-Katny and Cavieres 2012). A similar pattern is observed in the intertidal zone, an area strongly conditioned by salinity changes and large temperature fluctuations (Kuklinski and Balazy 2014), that constitutes one of the environments with the greatest biodiversity in the Maritime Antarctic. Marine algae are very abundant in these areas and are often used by penguins and pinnipeds typical of the Maritime Antarctic to lay on, particularly elephant seals.

\section{The Historical Heritage}

The SSI is associated with the oldest process of human occupation in the Antarctic continent during the early nineteenth century. Since 1820 , several companies from different countries started the first marine resource exploitation in the region (Slaney 1921; Martin 1940; Stackpole 1955; Bertrand 1971; Hodge 1976; Fitte 1982; Destéfani 1988; Berguño 1993a, b) within the process of expansion of the economic capitalist system (Zarankin and Senatore 2005).

Traditionally, the official history of Antarctica has been focused on the stories of heroes and important historical figures, ignoring ordinary people and subordinate groups throughout the process of discovery of this continent. This is the case with sealers and whalers, who led these first human settlements in Antarctica (Zarankin and Senatore 2005). However, little is known about these earliest settlers who lived in Antarctica during the summer months. Only recently, the study of the camps of Antarctic sealers has emerged as an interesting way to learn more about a history that had been neglected until recently (Zarankin and Senatore 2007).

In this sense, Elephant Point can be considered as one of the areas with the highest density of archaeological sites from the early nineteenth century in the entire Antarctic continent. Therefore, the area shows great potential to unveil the unsolved issues of the first sealers, especially concerning the calendar and frequency of its occupation. Despite its small size, five different archaeological sites were identified in Elephant Point. The archaeological material collected in this small peninsula is currently being examined, as well as some soil samples that are now being analysed in order to determine the physical and chemical components of archaeological soils. However, taking into account the spatial distribution of the sites and the preliminary artefactual analysis, we interpret that sites EP-2 and EP-X1 were contemporary and complementary: whilst EP-2 was used for shelter and living (eat and sleep); EP-X1 was the working area where sea elephants were boiled to produce the oil.

The excellent state of preservation of the site EP-2 is certainly remarkable, and it can be considered as probably the best preserved archaeological site in Antarctica. This must be related to its location (Fig. 4), almost covered by ice and snow all year round, which protects it from animals and extreme winds.

\section{Future Perspectives in Elephant Point in the Context of Maritime Antarctica}

The response of the glaciers in the Antarctic Peninsula region to one of the most pronounced warming rates recorded on Earth over the last half century (Turner et al. 2005; Steig et al. 2009) has shown large losses of glacier ice (Pritchard and Vaughan 2007; Cook and Vaughan 2010; Rignot et al. 2014). The climate scenarios for the next few decades reinforce the warming trend for the following decades (IPCC 2014); in consequence, many areas today covered by glaciers are expected to become ice-free in the near future. These environments will experience the same process that is occurring today - and has occurred during recent decades - in Elephant Point. But environmental changes in the Maritime Antarctic will not only be related to glacier retreat, but also to permafrost thawing. The proximity of permafrost to its climatic boundaries in the SSI (Vieira et al. 2010) suggests that this region should be one of the first areas in Antarctica to show the effects of climate change on permafrost state: small changes in moisture and/or temperature regimes may trigger significant changes in geomorphodynamics. Therefore, a thorough understanding of the current dynamics in the terrestrial icefree ecosystem of Elephant Point can give insights into the possible future environmental evolution in many areas of the Maritime Antarctic.

Most of the environmentally protected areas in the SSI have been defined by a single or limited number of values, with the purpose of being protected for future generations (Hughes and Convey 2010). By contrast, Elephant Point stands out as a natural laboratory where the complex interactions between changing geomorphological processes and ecological dynamics define a unique terrestrial ecosystem that 
should be examined in deeper detail and preserved. Together with this unique geoecological framework is the fact that Elephant Point constitutes an area without scientific or tourist pressure within the SSI, the most visited region by tourists in Antarctica (Serrano 2002; Enzenbacher 2007). In the nearby Byers Peninsula, an average of 33 researchers per year have visited the area for scientific purposes over recent years (Pertierra and Hughes 2013).

Many of the ASPAs have also been designated to protect them from external interferences from technicians, scientists or tourists in regions with intense human activity (Liggett et al. 2011), but this is not the case for Elephant Point, which is hardly visited by scientists and never by tourists. Therefore, additional environmental protection of this peninsula provided by an ASPA designation would be easier to implement at the same time that it would attract more scientists to this pristine ecosystem to examine the environmental dynamics in a rapidly changing coastal ecosystem representative of the Maritime Antarctic region.

Furthermore, the historical human occupation of the peninsula with several archaeological sites - some of them in very well-preserved condition-constitutes another value that should be taken into account. Therefore, Elephant Point accomplishes not only one but all of the outstanding values suggested by the Secretariat of the Antarctic Treaty for the ASPAs to be designated (environmental, scientific, historic, aesthetic or wilderness). Indeed, the small Elephant Point peninsula, with $1.16 \mathrm{~km}^{2}$, would fit within the $55 \%$ of the ASPAs that have an extension lower than $3 \mathrm{~km}^{2}$.

In conclusion, based on the findings presented in this paper, it is highly recommended to implement more environmental protection in the ice-free area of Elephant Point. The ASPA designation seems to be the most appropriate considering the geoecological and historical values existing in this small peninsula.

\section{Conclusions}

Despite its reduced size, the ice-free area of Elephant Point constitutes an excellent example of the interaction between the major morphogenetic systems, plant communities and fauna representative of the South Shetland archipelago, in particular, and of the Maritime Antarctic in general. In the context of fast-warming temperatures forecast for the next few decades, Elephant Point constitutes a unique environment for examining the different elements influencing this terrestrial ecosystem and to anticipate future ice-free scenarios in a rapidly deglaciating Antarctic Peninsula region.

This archipelago constitutes a key area to better understanding future climate and environmental scenarios within the Maritime Antarctic due to the proximity of the mean annual temperatures of the isotherm of $0{ }^{\circ} \mathrm{C}$. In the case of the ice-free environment of Elephant Point, the landscape is a consequence both of the long- and short-term glacier retreat of the Rotch dome. Six different geoecological environments have been identified in Elephant Point: Rotch glacier, proglacial environment, moraine system, bedrock plateaus, marine terraces and present-day beach. The ecological distribution of fauna and flora in Elephant Point is strongly conditioned by the geomorphological processes, which in turn are controlled by the age of deglaciation of the different environments in this peninsula. Whilst the glacier and the recently deglaciated surfaces show only some mosses, lichens and scant presence of animals, the oldest ice-free environments show a very rich biodiversity typical of the Maritime Antarctic.

Apart from this geoecological heritage, several archaeological sites show evidence of the historical importance that Elephant Point had over the last two centuries regarding the first sealers and early human economic activities in Antarctica. Some of these sites are among those better preserved from the early human colonisation of Antarctica, showing evidence of the daily life of the first settlers.

With the main purpose of preserving this geoecological and historical heritage, a higher degree of environmental protection is proposed to be implemented in Elephant Point, ideally under its designation as an ASPA.

Acknowledgments M. Oliva thanks the AXA Research Fund for sponsoring his research, and A. Casanova-Katny acknowledges the support of the General Directorate of Research and Postgraduate Studies of the Catholic University of Temuco, DGIPUCT $\mathrm{N}^{\circ}$ CD2010-01. This study was financially supported by the Portuguese Polar Program (PROPOLAR) and the research project HOLOANTAR (Holocene environmental change in the Maritime Antarctic. Interactions Between permafrost and the lacustrine environment), both funded by the Portuguese Science Foundation. Funding was also provided by the project 1120895 of the FONDECYT (Fondo Nacional de Desarrollo Científico y Tecnológico, Chile). The archaeological research has been funded by the PROANTAR/CNPq (Brazil). We acknowledge the Brazilian and Chilean Antarctic programmes for their logistic support in the field.

\section{References}

Anesio AM, Laybourn-Parry J (2012) Glaciers and ice sheets as a biome. Trends Ecol Evol 27:219-225

Anesio AM, Mindl B, Laybourn-Parry J, Hadson AJ, Sattler B (2007) Viral dynamics in cryoconite holes on a high Arctic glacier (Svalbard). Jof Geophys Res 112:G04S31. doi:10.1029/ 2006JG000350

Bañón M, Justel A, Velázquez D, Quesada A (2013) Regional weather survey on Byers Peninsula, Livingston Island, South Shetland Islands, Antarctica. Antarct Sci 25:146-156

Benayas J, Pertierra L, Tejedo P, Lara F, Bermúdez O, Hughes KA, Quesada A (2013) A review of scientific research trends within ASPA no. 126 Byers Peninsula, South Shetland Islands, Antarctica. Antarct Sci 25(2):128-145 
Berguño J (1993a) Las Shetland del Sur: el ciclo lobero. Primera parte Bol Antarct Chileno:5-13

Berguño J (1993b) Las Shetland del Sur: el ciclo lobero. Segunda parte Bol Antarct Chileno:2-9

Bertrand K (1971) Americans in the Antarctica. 1775-1948, Am Geogr Soc. Special Publication, New York, p. 39

Casanova-Katny MA, Cavieres LA (2012) Antarctic moss carpets facilitate growth of Deschampsia Antarctica but not its survival. Polar Biol 35:1869-1878

Convey P, Hughes KA, Tina T (2012) Continental governance and environmental management mechanisms under the Antarctic Treaty System: sufficient for the biodiversity challenges of this century? Biodivers 13(3-4):234-248

Cook AJ, Vaughan DG (2010) Overview of areal changes of the ice shelves on the Antarctic Peninsula over the past 50 years. Cryosphere 4:77-98

del Valle RA, Montalti D, Inbar M (2002) Mid-Holocene macrofossilbearing raised marine beaches at Potter Peninsula, King George Island, South Shetland Islands. Antarct Sci 14:263-269

Destéfani L (1988) La expedición española de 1819 y el Navío San Telmo. Investigaciones y Ensayos 38:77-107

Emslie SD (1995) Age and taphonomy of abandoned penguin rockeries in the Antarctic Peninsula Region. Polar Rec 3:409-418

Enzenbacher D (2007) Antarctic tourism policy-making. In: Triggs G, Riddell A (eds) Antarctica: legal and environmental challenges for the future. British Institute of International and Comparative Law, London, pp. 155-189

Fitte E (1982) Crónicas del Atlántico Sur: Patagonia, Malvinas y Antártida. EMECE, Buenos Aires

Fretwell PT, Hodgson DA, Watcham EP, Bentley MJ, Roberts SJ (2010) Holocene isostatic uplift of the South Shetland Islands, Antarctic Peninsula, modelled from raised beaches. Quat Sci Rev 29: $1880-1893$

Hodge J (1976) El Extremo Sur de América., Ed. América, Washington D.C.

Hughes KA, Convey P (2010) The protection of Antarctic terrestrial ecosystems from inter- and intra-continental transfer of nonindigenous species by human activities: a review of current systems and practices. Glob Environ Chang 20:96-112

Hughes KA, Pertierra LR, Walton DWH (2013) Area protection in Antarctica: how can conservation and scientific research goals be managed compatibly? Environ Sci Pol 31:120-132

IPCC (2014) Intergovernmental panel on climate change. World Meteorological Organization, Geneva

Ives JD, Barry RG (1974) Arctic and alpine environments. Methuen, London

King M, Padman L (2005) Accuracy assessment of ocean tide models around Antarctica. Geophys Res Lett 32:L23608. doi:10.1029/ 2005GL023901

Kuklinski P, Balazy P (2014) Scale of temperature variability in the maritime Antarctic intertidal zone. J Sea Res 85:542-546

Liggett DA, McIntosh A, Thompson A, Gilbert N, Storey B (2011) From frozen continent to tourism hotspot? Five decades of Antarctic tourism development and management, and a glimpse into the future. Tour Manag 32(2):357-366

López-Martínez J, Serrano E (2002) Geomorphology of Deception Island. In: López-Martínez J, Smellie JL, Thomson JW, Thomson MRA (eds) Geology and Geomorphology of Deception Island. British Antarctic Survey, Geomap Series, Cambridge, pp. 31-39

López-Martínez J, Serrano E, Schmid T, Mink S and Linés C (2012) Periglacial processes and landforms in the South Shetland Islands (northern Antarctic Peninsula region). Geomorphology 155:62-79

Macheret Y, Otero J, Navarro FJ, Vasilenko EV, Corcuera MI, Cuadrado ML, Glazovsky AF (2009) Ice thickness, internal structure and subglacial topography of Bowles Plateau ice cap and the main ice divides of Livingston Island, Antarctica, by ground-based radio-echo sounding. Ann Glaciol 50(51):49-56

Martin L (1940) Antarctica discovered by a Connecticut Yankeee, Captain Nathiel Brown Palmer. Geogr Rev 30(4):529-562

Michel RFM, Schaefer CEGR, López-Martínez J, Simas FNB, Haus NW, Serrano E, Bockheim J (2014) Soils and landforms from Fildes Peninsula and Ardley Island, Maritime Antarctica. Geomorphology 225:76-86

Michel RFM, Schaefer CEGR, Dias LE, Simas FNB, Melo-Benites V, Sá Mendonça E (2006) Ornithogenic Gelisols (Cryosols) from Maritime Antarctica. Soil Sci Soc Am J 70(4):1370-1376

Mieczan T, Górniak D, Świątecki A, Zdanowski M, TarkowskaKukuryk M (2013) The distribution of ciliates on ecology glacier (King George Island, Antarctica): relationships between species assemblages and environmental parameters. Polar Biol 36(2):249-258

Mora C, Vieira G, Pina P, Lousada M, Christiansen HH (2015) Land cover classification using high-resolution aerial photography in Adventdalen. Svalbard Geogr Ann A. doi:10.1111/geoa.12088

Oliva M, Ruiz-Fernández J (2015) Coupling patterns between paraglacial and permafrost degradation responses in Antarctica. Earth Surf Process Landf. doi:10.1002/esp.3716

Oliva M, Antoniades D, Giralt S, Granados I, Toro M, Pla-Rabes S, Vieira G (2014) La deglaciación holocena de la península Byers (isla Livingston, Antártida Marítima) a partir de la datación de sedimentos lacustres. Avances de la Geomorfología en España 2012-2014:523-526

Osmanoglu B, Navarro FJ, Hock R, Braun M, Corcuera MI (2014) Surface velocity and mass balance of Livingston Island ice cap, Antarctica. Cryosphere 8:1807-1823

Pertierra LR, Hughes KA (2013) Management of Antarctic Specially Protected Areas: permitting, visitation and information exchange practices. Antarct Sci 25(4):553-564

Pritchard HD, Vaughan DG (2007) Widespread acceleration of tidewater glaciers on the Antarctic Peninsula. J Geophys Res Earth Surf (2003-2012) 112(F3):F03S29. doi:10.1029/2006JF000597

Quesada A, Camacho A, Lyons WB (2013) Multidisciplinary research on Byers Peninsula, Livingston Island: a future benchmark for change in Maritime Antarctica. Antarct Sci 25(2):123-127

Remias D, Wastian H, Lütz C, Leya T (2013) Insights into the biology and phylogeny of Chloromonas polyptera (Chlorophyta), an alga causing orange snow in Maritime Antarctica. Antarct Sci 25(5): 648-656

Rignot E, Mouginot J, Morlighem M, Seroussi H, Scheuchl B (2014) Widespread, rapid grounding line retreat of Pine Island, Thwaites, Smith and Kohler glaciers, West Antarctica from 1992 to 2011. Geophys Res Lett 41(10):3502-3509

Serrano E (2002) Hielo, montañas, mar y fauna: el turismo en las islas Shetland del Sur (Antártida marítima). Revue de Géographie Alpine 1(90):9-24

Serrano E, López-Martínez J, Cuchí JA, Durán JJ, Mink S, Navas A (2008) Permafrost in the South Shetland Islands (Maritime Antarctica): spatial distribution pattern. In: Kane DL, Hinkel KM (eds) Proceedings of 9th International Conference on Permafrost, vol 2. University of Alaska Fairbanks, Fairbanks, pp. 1621-1625

Slaney H (1921) Notice of the voyage of Edward Barnsfield, Master of his Majesty's Ship Andromache, to New South Shetland. Edinburgh philosophical Journal 4:345-348

Stackpole E (1955) The Voyages of the Hurton and the Huntress: the American sealers and the discovery of the continent of Antarctica. Nabu Press, Connecticut

Steig EJ, Schneider DP, Rutherford SD, Mann ME, Comiso JC, Shindell DT (2009) Warming of the Antarctic ice-sheet surface since the 1957 IGY. Nature 457:459-462 
Terauds A, Chown SL, Morgan F, Peat HJ, Watts DJ, Keys H, Convey P, Bergstrom DM (2012) Conservation biogeography of the Antarctic. Divers Distrib 18:726-741

Toro M, Camacho A, Rochera C, Rico E, Banon M, Fernández-Valiente E, Marco E, Justel A, Avendano MC, Ariosa Y, Vincent WF, Quesada A (2007) Limnological characteristics of freshwater ecosystems of Byers. Polar Biol 30(5):635-649

Torres-Mellado JA, Jaña R, Casanova-Katny MA (2011) Antarctic hairgrass expansion in the South Shetland archipelago and Antarctic Peninsula revisited. Polar Biol 34(11):1679-1688

Troll C (1968) Geoecology of the Mountainous regions of the Tropical Americas. Ferd. Dümmers Verlag, Bonn

Troll C (1972) Geoecology of the High-Mountain regions of Eurasia. Erdwissenschaftsliche Forschung der Akademie der Wissenschaften und der Literatur. Franz Steiner Verlag GMBH, Mainz

Troll C (1973) The upper timberlines in different climatic zones. Arct Alp Res 5(3):3-18

Turner J, Colwell SR, Marshall GJ, Lachlan-Cope TA, Carleton AM, Jones PD, Lagun V, Reid PA, Iagovkina S (2005) Antarctic climate change during last 50 years. Int J Climatol 25:279-294

Vera ML (2011) Colonization and demographic structure of Deschampsia Antarctica and Colobanthus quitensis along an altitudinal gradient on Livingston Island, South Shetland Islands, Antarctica. Polar Res 30:7146

Verbitsky J (2013) Antarctic tourism management and regulation: the need for change. Polar Rec 49(250):278-285

Vieira G, Bockheim J, Guglielmin M, Balks M, Abramov AA, Boelhouwers J, Cannone N, Ganzert L, Gilichinsky D, Goryachkin S, López-Martínez J, Raffi R, Ramos M, Schaefer C, Serrano E, Simas F, Sletten R, Wagner D (2010) Thermal state of permafrost and active-layer monitoring in the Antarctic: advances during the international polar year 2007-2008. Permafrost Periglac 21:182-197

Vieira G, Mora C, Pina P, Schaefer CE (2014) A proxy for snow cover and winter ground surface cooling: mapping Usnea sp. communities using high resolution remote sensing imagery (maritime Antarctica). Geomorphology 225:69-75

Watcham EP, Bentley MJ, Hodgson DA, Roberts SJ, Fretwell PT, Lloyd JM, Larter RD, Whitehouse PL, Leng MJ, Monien P, Moreton SG (2011) A new relative sea level curve for the South Shetland Islands, Antarctica. Quat Sci Rev 30:3152-3170

Zarankin A, Senatore MX (2005) Archaeology in Antarctica, 19th century capitalism expansion strategies. Int J Hist Archaeol 9(1):43-56

Zarankin A, Senatore MX (2007) Historias de un pasado en blanco; Arqueología Histórica Antártica. Argumentum, Belo Horizonte 